\title{
KINERJA PEGAWAI BALAI BESAR PENDIDIKAN DAN PELATIHAN KESEJAHTERAAN SOSIAL (BBPPKS) REGIONAL IV KALIMANTAN
}

\author{
Rizki Putri Amelia ${ }^{1}$,Achmad Alim Bachri' ${ }^{2}$ Jamaluddin $^{3}$ \\ ${ }^{1}$ Balai Besar Pendidikan dan Pelatihan Kesejahteraan Sosial (BBPPKS) \\ Regional IV Kalimantan) \\ ${ }^{2}$ Universitas Lambung Mangkurat Banjarmasin \\ ${ }^{3}$ Universitas Lambung Mangkurat Banjarmasin
}

\begin{abstract}
Abstrak
Tujuan penelitian adalah: 1. Untuk mengetahui kinerja pegawai pada Balai Besar Pendidikan dan Pelatihan Kesejahteraan Sosial (BBPPKS) Regional IV Kalimantan. 2. Untuk mengetahui permasalahan tentang kinerja yang sering terjadi pada Balai Besar Pendidikan dan Pelatihan Kesejahteraan Sosial (BBPPKS) Regional IV Kalimantan. Penelitian ini menggunakan desain penelitian deskriptif dengan pendekatan kualitatif. Teknik pengumpulan data yang digunakanmelalui wawancara, observasi dan dokumentasi. Informan penelitian diambil dari usul penentu kebijakan dan pemangku kepentingan. Teknik analisa data menggunakan analisis data interaktif yang terdiri dari reduksi data, penyajian data dan penarikan kesimpulan. Kinerja pegawai Balai Besar Pendidikan dan Pelatihan Kesejahteraan Sosial (BBPPKS) Regional IV Kalimantan dilihat dari dimensi tujuan kinerja pegawai, standar kinerja pegawai dan motif kinerja pegawai belum mencapai tingkat yang optimal. Sedangkan dari dimensi akuntabilitas kinerja pegawai sudah mulai mencapai tingkat yang optimal. Pembagian kerja di Balai Besar Pendidikan dan Pelatihan Kesejahteraan Sosial (BBPPKS) Regional IV Kalimantan secara formal telah merujuk pada peraturan mengenai tupoksi, namun demikian kadangkala terjadi pelimpahan pekerjaan kepada personil yang kurang sesuai dengan jabatannya. Disini terlihat bahwa responsibilitas kinerja pegawai pada Balai Besar Pendidikan dan Pelatihan Kesejahteraan Sosial (BBPPKS) Regional IV Kalimantan belum dikatakan pelaksanaannya selaras dengan prosedur yang ditetapkan.
\end{abstract}

Kata kunci: kinerja dan pegawai

\begin{abstract}
The purpose of this research is: 1. To know performance employees at of big hall education and training social welfare (BBPPKS) regional IV of Kalimantan. 2. To know problems of performance often occurs in big hall education and training social welfare (BBPPKS) regional IV of Kalimantan. This study used a descriptive research design with qualitative approach. Data collection techniques used through interviews, observation and documentation. Informants were taken from origin policy makers and stakeholders. Analysis using interactive data analysis which consists of data reduction, data presentation and conclusion. The results show that the employee performance research big hall education and training social welfare (BBPPKS) regional IV of Kalimantan seen the purpose the employee performance, the employee performance standards and motives have not reached the level the employee performance levels while the accountability the employee performance has begun to reach this optimal. The distribution of work in education and training of big hall social welfare (BBPPKS) regional IV of Kalimantan formally have refer to the regulations concerning the formulation of the, however
\end{abstract}


sometimes the allocation of work to personnel less consistent with his position. Here it can be seen that responsibility the performance of on officer at of big hall for training and education of people with social welfare (BBPPKS) regional IV of Kalimantan as part of the has not yet been it is said the implementation of the activity aligned with the government of a prescribed procedure.

Keywords: performance and employees

\section{Pendahuluan}

Pegawai sebagai bagian dari sumber daya aparatur perlu dikembangkan. Didorong dan ditumbuhkan prakarsa dan kreativitas untuk mampu menunjukkan disiplin, kinerja dan produktivitas kerja yang optimal dalam menyelenggarakan tugas-tugas pelayanan publik dibidang pembangunan, pemerintahan dan kemasyarakatan.

Kinerja mempunyai arti penting bagi pegawai. Adanya penilaian kinerja berarti pegawai mendapat perhatian dari atasan, disamping itu akan menambah gairah kerja pegawai karena dengan penilaian kinerja ini mungkin pegawai yang berprestasi dipromosikan, dikembangkan dan diberi penghargaan atas prestasi, sebaliknya pegawai yang tidak berprestasi mungkin akan didemosikan.

Balai Besar Pendidikan dan Pelatihan Kesejahteraan Sosial (BBPPKS) Regional IV Kalimantan merupakan salah satu perwujudan dari program reformasi birokrasi di Kementerian Sosial RI dalam memberikan pelayanan kepada masyarakat maupun para stakeholder. Balai Besar Pendidikan dan Pelatihan Kesejahteraan Sosial (BBPPKS) Regional IV Kalimantan mempunyai tugas melaksanakan pendidikan dan pelatihan kesejahteraan sosial bagi tenaga kesejahteraan sosial pemerintah dan masyarakat, pengkajian dan penyiapan standarisasi pendidikan dan pelatihan, pemberian informasi serta koordinasi dengan instansi terkait sesuai dengan perundang-undangan yang berlaku.

Permasalahan kinerja pegawai dapat dilihat dari masih adanya pegawai yang keluar kantor di waktu jam kerja dengan kepentingan pribadi. Rendahnya disiplin pegawai dari hasil pengamatan awal menunjukkan bahwa di Balai Besar Pendidikan dan Pelatihan Kesejahteraan Sosial (BBPPKS) Regional IV Kalimantan masih ada beberapa pegawai yang datang tidak tepat waktu yang menyebabkan tertundanya pekerjaan yang seharusnya diselesaikan tepat pada hari itu juga. Selain itu, ada pula pegawai yang tidak dapat mengerjakan pekerjaan sesuai dengan target yang telah ditentukan. Ketika seorang pegawai tidak bisa menyelesaikan pekerjaan dengan benar dan mengandalkan tugas yang dibebankan kepada pegawai lain ini menunjukkan bahwa kinerja pegawai Balai Besar Pendidikan dan Pelatihan Kesejahteraan Sosial (BBPPKS) Regional IV Kalimantan belum optimal. Pelimpahan tugas pokok yang seharusnya dikerjakan oleh pegawai yang bersangkutan kepada tenaga kontrak masih sering terjadi. Hal ini dikarenakan pegawai tersebut merasa bahwa tugas tersebut sudah tidak sesuai lagi kalau mereka yang mengerjakan, sehingga pegawai tersebut sering melimpahkan tugas pokoknya tersebut kepada tenaga kontrak. Sering juga alasan sebagai regenerasi digunakan pegawai untuk melimpahkan tugas pokoknya kepada tenaga kontrak. 
Rincian Capaian Output Kegiatan Indikator Kinerja BBPPKS Banjarmasin Tahun 2017

\begin{tabular}{|c|c|c|c|}
\hline Sasaran Strategis & $\begin{array}{c}\text { Indikator Kinerja } \\
\text { (Output) }\end{array}$ & $\begin{array}{c}\text { Target PK } \\
\text { Revisi }\end{array}$ & Realisasi \\
\hline \multirow{5}{*}{$\begin{array}{l}\text { Meningkatnya } \\
\text { kualitas } \\
\text { penyelenggaraan } \\
\text { diklat bagi SDM } \\
\text { Kesos }\end{array}$} & $\begin{array}{l}\text { Jumlah penyelenggaraan diklat bagi SDM } \\
\text { Kesos aparatur yang memenuhi standar } \\
\text { nasional }\end{array}$ & $\begin{array}{l}4 \text { angkatan } \\
\text { (130 orang) }\end{array}$ & $\begin{array}{l}4 \text { angkatan } \\
\text { (127 orang) }\end{array}$ \\
\hline & $\begin{array}{l}\text { Output : } \\
\text { 1. Terlatihnya } 30 \text { orang TKSP yang } \\
\text { mengikuti diklat pendidikan dasar } \\
\text { pekerjaan sosial }\end{array}$ & 30 orang & 30 orang \\
\hline & $\begin{array}{l}\text { 2. Terlatihnya } 40 \text { orang TKSP yang } \\
\text { mengikuti diklat manajemen } \\
\text { pembangunan kesejahteraan sosial }\end{array}$ & 40 orang & 37 orang \\
\hline & $\begin{array}{l}\text { 3. Terlatihnya } 30 \text { orang TKSP yang } \\
\text { mengikuti diklat perlindungan anak }\end{array}$ & 30 orang & 30 orang \\
\hline & $\begin{array}{l}\text { 4. Terlatihnya } 30 \text { orang TKSP yang } \\
\text { mengikuti diklat anak berhadapan } \\
\text { dengan hokum }\end{array}$ & 30 orang & 30 orang \\
\hline
\end{tabular}

Sumber: BBPPKS Banjarmasin

\section{Rumusan Masalah}

Berpangkal tolak dari persoalanpersoalan yang telah dikemukakan di atas maka perumusan masalah dalam studi penelitian ini dapat dirumuskan sebagai berikut:

1. Bagaimana kinerja pegawai Balai Besar Pendidikan dan Pelatihan Kesejahteraan Sosial (BBPPKS) Regional IV Kalimantan?

2. Mengapa masih sering terjadi pelimpahan tugas pokok pegawai kepada tenaga kontrak di Balai Besar Pendidikan dan Pelatihan Kesejahteraan Sosial (BBPPKS) Regional IV Kalimantan?

\section{Kerangka Teori}

\section{Konsep Kinerja}

Konsep kinerja pada dasarnya dapat dilihat dari dua segi, yaitu kinerja pegawai (perindividu) dan kinerja organisasi. Kinerja pegawai adalah hasil kerja perseorangan dalam suatu organisasi. Sedangkan kinerja organisasi adalah totalitas hasil kerja yang dicapai suatu organisasi. Kinerja pegawai dan kinerja organisasi memiliki keterkaitan yang sangat erat. Tercapainya tujuan organisasi tidak bisa dilepaskan dari sumber daya yang dimiliki oleh organisasi yang digerakkan atau dijalankan pegawai yang berperan aktif sebagai pelaku dalam upaya mencapai tujuan organisasi tersebut.

\section{Indikator Kinerja}

Hersey, Blanchard dan Johnson (1996:386) dalam Wibowo (2017:86-88) terdapat tujuh indikator kinerja, antara lain:

a. Tujuan

Tujuan merupakan keadaan yang berbeda yang secara aktif dicari oleh seorang individu atau organisasi untuk dicapai. Pengertian tersebut mengandung makna bahwa tujuan bukanlah merupakan persyaratan, juga bukan merupakan sebuah keinginan.

Tujuan merupakan sesuatu keadaan yang lebih baik yang ingin dicapai dimasa yang akan datang. Dengan demikian, tujuan menunjukkan arah kemana kinerja harus dilakukan. Atas dasar arah tersebut, dilakukan kinerja untuk mencapai tujuan. Untuk mencapai tujuan, diperlukan 
kinerja individu, kelompok dan organisasi. Kinerja individu maupun organisasi berhasil apabila dapat mencapai tujuan yang diinginkan.

b. Standar

Standar mempunyai arti penting karena memberitahukan kapan suatu tujuan dapat diselesaikan. Standar merupakan suatu ukuran apakah tujuan yang diinginkan dapat dicapai. Tanpa standar, tidak dapat diketahui kapan suatu tujuan tercapai.

Standar menjawab pertanyaan tentang kapan kita tahu bahwa kita sukses atau gagal. Kinerja seseorang dikatakan berhasil apabila mampu mencapai standar yang ditentukan atau disepakati bersama antara atasan dan bawahan.

c. Umpan Balik

Antara tujuan, standard an umpan balik bersifat saling terkait. Umpan balik melaporkan kemajuan, baik kualitas maupun kuantitas, dalam mencapai tujuan yang didefinisikan oleh standar. Umpan balik terutama penting ketika kita mempertimbangkan "real goals" atau tujuan sebenarnya. Tujuan yang dapat diterima oleh pekerja adalah tujuan yang bermakna dan berharga. Umpan balik merupakan masukan yang dipergunakan untuk mengukur kemajuan kinerja, standar kinerja dan pencapaian tujuan. Dengan umpan balik dilakukan evaluasi terhadap kinerja dan sebagai hasilnya dapat dilakukan perbaikan kinerja.

d. Alat atau Sarana

Alat atau sarana merupakan sumber daya yang dapat dipergunakan untuk membantu menyelesaikan tujuan dengan sukses. Alat atau sarana merupakan faktor penunjang untuk pencapaian tujuan. Tanpa alat atau sarana, tugas pekerjaan spesifik tidak dapat dilakukan dan tujuan tidak dapat diselesaikan sebagaimana seharusnya. Tanpa alat tidak mungkin dapat melakukan pekerjaan.

e. Kompetensi

Kompetensi merupakan persyaratan utama dalam kinerja. Kompetensi merupakan kemampuan yang dimiliki oleh seseorang untuk menjalankan pekerjaan yang diberikan kepadanya dengan baik. Orang harus melakukan lebih dari sekedar belajar tentang sesuatu, orang harus dapat melakukan pekerjaannya dengan baik. Kompetensi memungkinkan seseorang mewujudkan tugas yang berkaitan dengan pekerjaan yang diperlukan untuk mencapai tujuan.

f. Motif

Motif merupakan alasan atau pendorong bagi seseorang untuk melakukan sesuatu. Manajer memfasilitasi motivasi kepada karyawan dengan insentif berupa uang, memberikan pengakuan, menetapkan tujuan menantang, menetapkan standar terjangkau, meminta umpan balik, memberikan kebebasan melakukan pekerjaan termasuk waktu melakukan pekerjaan, menyediakan sumber daya yang diperlukan dan menghapuskan tindakan yang mengakibatkan disintensif.

g. Peluang

Pekerja perlu mendapatkan kesempatan untuk menunjukkan prestasi kerjanya. Terdapat dua faktor yang menyumbangkan pada adanya kekurangan kesempatan untuk berprestasi, yaitu ketersediaan waktu dan kemampuan untuk memenuhi syarat.

Tugas mendapatkan prioritas lebihtinggi, mendapat perhatian lebih banyak dan mengambil waktu yang tersedia. Jika pekerja dihindari 
karena supervisor tidak percaya terhadap kualitas atau kepuasan konsumen, mereka secara efektif akan dihambat dari kemampuan memenuhi syarat untuk berprestasi.

\section{Faktor-Faktor yang Mempengaruhi Kinerja}

Faktor-faktor yang mempengaruhi kinerja pegawai menurut Mathis dan Jackson (2012) dalam Priansa (2017:50) adalah sebagai berikut:

a. Kemampuan Individual

Mencakup bakat, minat dan faktor kepribadian. Tingkat keterampilan merupakan bahan mentah yang dimiliki oleh seseorang berupa pengetahuan, pemahaman, kemampuan, kecakapan interpersonal dan kecakapan teknis. Dengan demikian, kemungkinan seorang pegawai mempunyai kinerja yang baik, jika kinerja pegawai tersebut memiliki tingkat keterampilan baik, pegawai tersebut akan menghasilkan yang baik pula.

b. Usaha yang Dicurahkan

Usaha yang dicurahkan bagi pegawai adalah ketika kerja, kehadiran dan motivasinya. Tingkat usahanya merupakan gambaran motivasi yang diperlihatkan pegawai untuk menyelesaikan pekerjaan dengan baik. Oleh karena itu, jika pegawai memiliki tingkat keterampilan untuk mengerjakan pekerjaan, ia tidak akan bekerja dengan baik jika hanya sedikit upaya. Hal ini berkaitan dengan perbedaan antara tingkat keterampilan dan tingkat upaya. Tingkat keterampilan merupakan cerminan dari kemampuan yang dilakukan sedangkan tingkat upaya merupakan cermin dari sesuatu yang dilakukan.

c. Lingkungan Organisasional

Di lingkungan organisasional perusahaan menyediakan fasilitas bagi pegawai yang meliputi pelatihan dan pengembangan, peralatan, teknologi dan manajemen.

\section{Standar Kinerja}

Wirawan (2009:68-69) standar kinerja perlu memenuhi persyaratan berikut agar dapat digunakan sebagai tolak ukur dalam mengukur kinerja, antara lain:

a. Ada hubungan relevansinya dengan strategi perusahaan.

b. Mencerminkan keseluruhan tanggungjawab karyawan dalam melaksanakan pekerjaannya.

c. Memperhatikan pengaruh faktorfaktor di luar kontrol karyawan.

d. Memperhatikan teknologi dan proses produksi.

e. Sensitif, mampu membedakan antara kinerja yang dpat diterima dan tidak dapat diterima.

f. Memberikan tantangan kepada para karyawan.

g. Realistis.

h. Berhubungan dengan kerangka waktu pencapaian standar.

i. Dapat diukur dan ada alat ukur untuk mengukur standar.

j. Standar harus konsisten.

k. Standar harus adil.

1. Memenuhi ketentuan undang-undang dan peraturan ketenagakerjaan.

\section{Dimensi yang Menunjang Kinerja}

Dimensi yang menjadi tolak ukur untuk menilai kinerja mennurut John Miner (1988) dalam Edison, Yohny Anwar dan Imas Komariyah (2017:192-193) yaitu:

a. Kualitas

Yaitu tingkat kesalahan, kerusakan, kecermatan.

b. Kuantitas

Yaitu jumlah pekerjaan yang dihasilkan.

c. Penggunaan Waktu dalam Kerja Yaitu tingkat ketidakhadiran, keterlambatan, waktu kerja efektif atau jam kerja hilang. 


\section{d. Kerjasama dengan Orang Lain dalam Bekerja.}

\section{Konsep Kepegawaian}

Undang-Undang Republik Indonesia Nomor 43 Tahun 1999 tentang pokok-pokok kepegawaian, Pasal 1 angka 1 menyebutkan bahwa pegawai negeri adalah setiap warga negara republik Indonesia yang telah memenuhi syarat yang ditentukan, diangkat oleh pejabat yang berwenang dan diserahi tugas negara lainnya dan digaji berdasarkan peraturan perundangan yang berlaku. Pasal 3 ayat 1 menyebutkan pegawai negeri berkedudukan sebagai aparatur negara yang bertugas untuk memberikan pelayanan kepada masyarakat secara profesional, jujur, adil dan merata dalam penyelenggaraan tugas Negara, pemerintahan dan pembangunan.

Pegawai negeri adalah unsur aparatur negara, abdi negara dan abdi masyarakat yang penuh dengan kesetiaan dan ketaatan kepada Pancasila, UUD 1945, Negara dan Pemerintah menyelenggarakan tugas pemerintahan dan pembangunan. Pegawai negeri sipil sebagai aparatur Negara yang bertugas membantu Presiden sebagai kepala pemerintahan dalam menyelenggarakan pemerintahan, tugas melaksanakan peraturan perundang-undangan dalam arti kata wajib mengusahakan agar setiap peraturan perundang-undangan ditaati oleh setiap masyarakat. Dalam melaksanakan peraturan perundang-undangan pada umumnya pegawai negeri sipil diberikan tugas kedinasan untuk melaksanakan tugas tersebut dengan sebaik-baiknya.

Sebagai abdi negara dan abdi masyarakat setiap pegawai negeri sipil harus mampu meletakkan kepentingan negara dan kepentingan masyarakat diatas kepentingan pribadi dan golongan. Sebagai abdi negara seorang pegawai negeri juga wajib setia dan taat kepada Pancasila sebagai falsafah dan ideology Negara, kepada UUD 1945, negara dan pemerintahan.

Pegawai negeri harus bersikap monoloyalitas sehingga setiap pegawai negeri sipil dapat memusatkan segala perhatian dan pikiran serta menyerahkan daya dan tenaga untuk menyelenggarakan tugas pemerintahan dan pembangunan serta berdaya guna. Kesetiaan dan ketaatan penuh yang berarti pegawai negeri sipil sepenuhnya berada dibawah pimpinan pemerintahan dan sebagai abdi masyarakat. Pegawai negeri harus memberikan pelayanan yang sebaik-baiknya kepada masyarakat.

Undang-Undang Republik Indonesia Nomor 5 Tahun 2014 tentang aparatur sipil negara, Pasal 1 menjelaskan tentang:

a. Aparatur Sipil Negara yang selanjutnya disingkat ASN adalah profesi bagi pegawai negeri sipil dan pegawai pemerintah dengan perjanjian kerja yang bekerja pada instansi pemerintah.

b. Pegawai Aparatur Sipil Negara yang selanjutnya disebut Pegawai ASN adalah pegawai negeri sipil dan pegawai pemerintah dengan perjanjian kerja yang diangkat oleh pejabat Pembina kepegawaian dan diserahi tugas dalam suatu jabatan pemerintahan atau diserahi tugas Negara lainnya dan digaji berdasarkan peraturan perundangundangan.

c. Pegawai Negeri Sipil yang selanjutnya disingkat PNS adalah warga Negara Indonesia yang memenuhi syarat tertentu, diangkat sebagai Pegawai ASN secara tetap oleh pejabat Pembina kepegawaian untuk menduduki jabatan pemerintahan.

d. Pegawai Pemerintah dengan Perjanjian Kerja yang selanjutnya disingkat PPPK adalah warga Negara Indonesia yang memenuhi syarat tertentu, yang diangkat berdasarkan perjanjian kerja untuk jangka waktu tertentu dalam rangka melaksanakan tugas pemerintahan.

Pasal 6 Undang-Undang Republik Indonesia Nomor 5 Tahun 2014 tentang 
aparatur sipil negara menjelaskan tentang pegawai ASN terdiri atas:

a. PNS

PNS sebagaimana dimaksud pegawai ASN yang diangkat sebagai pegawai tetap oleh pejabat pembina kepegawaian dan memiliki nomor induk pegawai secara nasional.

b. PPPK

PPPK sebagaimana dimaksud merupakan pegawai ASN yang diangkat sebagai pegawai dengan perjanjian kerja oleh pejabat pembina kepegawaian sesuai dengan kebutuhan instansi pemerintah dan ketentuan Undang-Undang.

\section{Metode Penelitian}

\section{Pendekatan Penelitian}

Penelitian ini menggunakan pendekatan kualitatif. Penelitian kualitatif menurut David William (1995) dalam buku Lexi. J. Moleong (2007) adalah pengumpulan data pada suatu latar alamiah dengan menggunakan metode alamiah dan dilakukan oleh orang atau peneliti yang tertarik secara alamiah.

\section{Tipe Penelitian}

Penelitian ini menggunakan metode penelitian deskriptif kualitatif. Penelitian deskriptif kualitatif menurut Nazir (2003) adlah suatu metode dalam meneliti status kelompok manusia, suatu objek, suatu kondisi, suatu sistem pemikiran maupun suatu kelas peristiwa pada masa sekarang.

\section{Teknik Pengumpulan Data}

Teknik pengumpulan data yang digunakan merupakan kombinasi dari beberapa teknik, yaitu:

a. Wawancara

Cholid dan Achmadi (1997)
berpendapat bahwa metode
wawancara adalah proses Tanya
jawab dalam penelitian yang
berlangsung secara lisan dimana
dua orang atau lebih bertatap

muka mendengarkan secara langsung informasi-informasi atau keterangan-keterangan.

b. Observasi

Observasi atau yang lebih umum dikenal dengan pengamatan menurut Moleong (2005) adalah kegiatan untuk mengoptimalkan kemampuan peneliti dari segi motif, kepercayaan, perhatian, perilaku tidak sadar, kebiasaan dan sebagainya.

c. Dokumentasi

Dokumen merupakan salah satu sumber data sekunder yang diperlukan dalam sebuah penelitian. Menurut Guba dan Lincoln dokumen adalah setiap bahan tertulis ataupun film, gambar dan foto-foto yang dipersiapkan karena adanya permintaan seorang penyidik (Moleong, 2005).

\section{Teknik Analisa Data}

Miles and Huberman (1984) mengemukakan bahwa aktivitas dalam analisis data kualitatif dilakukan secara interaktif dan berlangsung secara terus menerus sampai tuntas sehingga datanya jenuh. Ukuran kejenuhan data ditandai dengan tidak diperolehnya lagi data atau informasi baru. Aktivitas dalam analisis meliputi:

a. Tahap Reduksi Data

Reduksi data merupakan proses berpikir sensitive yang memerlukan kecerdasan dan keluasan dan kedalaman wawasan yang dapat mendiskusikan pada teman atau pada orang yang dipandang ahli. Melalui diskusi itu maka wawancara peneliti akan berkembang sehingga dapat mereduksi data-data yang memiliki nilai temuan dan pengembangan teori yang signifikan.

b. Tahap Penyajian Data

Penyajian data yakni penyajian data yang dilakukan dalam bentuk uraian singkat, bagan, hubungan antar kategori, flowchart dan sejenisnya 
nantinya data terorganisir tersusun dalam pola hubungan sehingga mudah dipahami. Yang paling sering digunakan untuk menyajikan data dalam penelitian kualitatif adalah dengan teks yang bersifat naratif.

c. Tahap Penarikan Kesimpulan dan Verifikasi

Verifikasi yakni menarik kesimpulan berdasarkan temuan dan melakukan verifikasi data.

\section{Lokasi Penelitian}

Penelitian tentang kinerja pegawai Balai Besar Pendidikan dan Pelatihan Kesejahteraan Sosial (BBPPKS) Regional IV Kalimantan dilakukan di kantor Balai Besar Pendidikan dan Pelatihan Kesejahteraan Sosial (BBPPKS) Regional IV Kalimantan yang terdapat di kota Banjarmasin dan kota Banjarbaru propinsi Kalimantan Selatan.

\section{Hasil dan Pembahasan}

\section{Kinerja Pegawai pada Balai Besar Pendidikan dan Pelatihan Kesejahteraan Sosial (BBPPKS) Regional IV Kalimantan}

Kinerja pegawai pada Balai Besar Pendidikan dan Pelatihan Kesejahteraan Sosial (BBPPKS) Regional IV Kalimantan yang dilihat dari beberapa dimensi, antara lain:

1. Tujuan Kinerja Pegawai

Berdasarkan hasil penelitian parameter yang digunakan untuk mengukur tujuan kinerja pegawai Balai Besar Pendidikan dan Pelatihan Kesejahteraan Sosial (BBPPKS) Regional IV Kalimantan adalah:

a. Komitmen Pegawai

Berdasarkan hasil penelitian penulis sebelumnya di lapangan terlihat bahwa komitmen pegawai di Balai Besar Pendidikan dan Pelatihan Kesejahteraan
Sosial (BBPPKS) Regional IV Kalimantan masih rendah. Ini terlihat dari sebagian pegawai masih belum mampu bekerja secara maksimal sehingga tujuan yang ingin diwujudkan belum tercapai.

Pengamatan penulis dilapangan terkadang pimpinan sendiri pun tidak melaksanakan komitmen yang telah disepakati bersama. Hal ini nantinya akan sangat berpengaruh terhadap pegawai tersebut, karena pegawai tersebut melihat pimpinannya sendiri tidak melaksanakan komitmen yang telah disepakati akhirnya pegawai sendiri pun akan dengan mudahnya melanggar komitmen yang telah disepakati tersebut.

Didalambirokrasipemerintahan sangat diperlukan sekali adanya komitmen pegawai. Antara pimpinan dengan pegawai harus memiliki komitmen yang jelas agar tujuan birokrasi dapat berjalan sesuai dengan tujuan yang ingin dicapai.

2. Standar Kinerja Pegawai

Berdasarkan hasil penelitian parameter yang digunakan untuk mengukur standar kinerja pegawai Balai Besar Pendidikan dan Pelatihan Kesejahteraan Sosial (BBPPKS) Regional IV Kalimantan adalah:

a. Hasil Kerja Pegawai Berdasarkan Kualitas Pekerjaan yang Dihasilkan

Hasil pengamatan penulis dilapangan terlihat bahwa yang menjadi kendala didalam kualitas pekerjaan yang dihasilkan adalah tidak memahaminya para pegawai dengan tugas pokok dan fungsinya. Ini akan berpengaruh 
terhadap penyelesaian pekerjaan pegawai tersebut.

Hasil pengamatan penulis sebenarnya sudah ada standar operasional pelaksanaan (SOP) yang didalamnya mencakup uraian tugas dari masingmasing pegawai tersebut. Tetapi karena para pegawai tersebut kurang memahami standar operasional pelaksanaan (SOP) tersebut sehingga ini akan berpengaruh terhadap penyelesaian pekerjaan para pegawai tersebut.

b. Hasil Kerja Pegawai Berdasarkan Kuantitas Pekerjaan yang Diselesaikan Hasil pengamatan penulis dilapangan terlihat masih banyak pegawai yang tidak memahami tugas pokok dan fungsinya sehingga mereka tidak dapat menyelesaikan pekerjaan dengan baik. Tetapi yang penulis perhatikan dilapangan masih saja terjadi pelimpahan tugas pokok dan fungsinya kepada orang lain yang bukan merupakan tugas pokok dan fungsi mereka, tetapi tidak ada tindakan tegas dari pimpinan. Biasanya yang melimpahkan tugas pokok dan fungsinya tersebut selalu beralasan karena mereka tidak memahami akan tugas pokok dan fungsi pekerjaan mereka sendiri.

3. Motif Kinerja Pegawai

Berdasarkan hasil penelitian parameter yang digunakan untuk mengukur motif kinerja pegawai Balai Besar Pendidikan dan Pelatihan Kesejahteraan Sosial (BBPPKS) Regional IV Kalimantan adalah:

a. Kedisiplinan Pegawai
Hasil pengamatan penulis dilapangan terlihat bahwa kedisiplinan pegawai masih kurang. Ini terlihat dari banyaknya para pegawai yang meninggalkan kantor pada saat jam kerja sehingga pekerjaan yang seharusnya dapat mereka selesaikan tepat waktu akhirnya terbengkalai karena pegawai tersebut tidak berada ditempat. Tetapi dari hasil pengamatan penulis dilapangan bahwa pimpinannya sendiri pun tidak pernah menegur apalagi memberikan sanksi kepada para pegawai yang tidak pernah berada ditempat kerja. Ini yang akhirnya membuat para pegawai merasa bebas tanpa ada beban karena pimpinannya sendiri tidak memperdulikannya.

Penulis juga mengamati pada saat jam masuk kantor dan pulang kantor. Ini sangat berbeda sekali pada saat pegawai tersebut berada di jam-jam kantor. Pada saat masuk kantor pegawai tersebut akan tepat waktu begitu juga dengan pulang kantor pegawai tersebut juga tepat waktu. Tetapi disisi lain pada saat jam kantor pegawai tersebut tidak berada ditempat. Ini yang menyebabkan banyak pekerjaan yang tidak selesai tepat pada waktu yang telah ditentukan.

b. Tanggungjawab Pegawai

Pengamatan penulis dilapangan bahwa banyak pegawai yang tidak masuk kerja tanpa ada keterangan tetapi mereka tetap melaksanakan absen harian. Disini dapat dilihat masih kurangnya tanggungjawab pegawai melaksanakan 
tugas dan pekerjaan yang

telah dibebankan kepada pegawai tersebut, padahal tanggungjawab pegawai tersebut adalah melaksanakan tugas dan pekerjaan yang telah dibebankan kepada pegawai dengan penuh kesadaran sesuai dengan aturan dan tepat pada waktunya.

c. Kemandirian Pegawai

Hasil pengamatan penulis dilapangan terlihat kemandirian pegawai sangat bervariasi dan ini dipengaruhi oleh tingkat pendidikan pegawai tersebut. Kemandirian pegawai dalam mengerjakan tugas dan tanggungjawab yang diembannya dipengaruhi oleh tingkat kualitas pegawai itu sendiri apakah dalam menjalankan fungsinya dapat bekerja sendiri atau mengharapkan bantuan dari orang lain.

4. Akuntabilitas Kinerja Pegawai Berdasarkan hasil penelitian parameter yang digunakan untuk mengukur akuntabilitas kinerja pegawai Balai Besar Pendidikan dan Pelatihan Kesejahteraan Sosial (BBPPKS) Regional IV Kalimantan adalah:

a. Penyampaian Laporan

Akuntabilitas Kinerja Instansi

Pemerintah

Hasil penelitian menunjukkan bahwa Balai Besar Pendidikan dan Pelatihan Kesejahteraan Sosial (BBPPKS) Regional IV Kalimantan telah menyusun laporan akuntabilitas kinerja instansi pemerintah (LAKIP) setiap tahunnya, format penyusunannya mengikuti ketentuan yang ada.

\section{Pengalihan Tugas Pokok Pegawai Kepada Tenaga Kontrak pada Balai Besar Pendidikan dan Pelatihan Kesejahteraan Sosial (BBPPKS) Regional IV Kalimantan}

Pembagian kerja di Balai Besar Pendidikan dan Pelatihan Kesejahteraan Sosial (BBPPKS) Regional IV Kalimantan secara formal telah merujuk pada peraturan mengenai tupoksi. Namun demikian kadangkala terjadi pelimpahan pekerjaan kepada personil yang kurang sesuai dengan jabatannya.

Hasil pengamatan penulis sebenarnya sudah ada standar operasional pelaksanaan (SOP) yang didalamnya mencakup uraian tugas dari masing-masing pegawai tersebut. Terkait dengan informasi yang didapat penulis menemukan data dilapangan bahwa sebenarnya sudah ada peraturan yang menjelaskan tentang pembagian kerja antara pegawai dan tenaga kontrak. Tetapi pada kenyataannya dilapangan yang penulis lihat masih banyak ketidaksesuaian antara peraturan dengan yang dilaksanakan.

Di salah satu sisi juga karena tidak adanya ketegasan dari pimpinan tentang pembagian kerja antara pegawai dan tenaga kontrak, apalagi yang sering dijadikan alasan oleh pimpinan adalah karena sudah banyak pegawai yang tua-tua yang akan pensiun sehingga pekerjaan dilimpahkan kepada tenaga kontrak karena tenaga kontrak yang ada masih muda-muda dan untuk regenerasi.

\section{Kesimpulan dan Saran}

\section{Kesimpulan}

a. Kinerja pegawai Balai Besar Pendidikan dan Pelatihan Kesejahteraan Sosial (BBPPKS) Regional IV Kalimantan dilihat dari dimensi tujuan kinerja pegawai, standar kinerja pegawai dan motif kinerja pegawai belum mencapai tingkat yang optimal. Sedangkan dari dimensi akuntabilitas kinerja pegawai sudah mulai mencapai 
tingkat yang optimal.

b. Responsibilitas kinerja pegawai pada Balai Besar Pendidikan dan Pelatihan Kesejahteraan Sosial (BBPPKS) Regional IV Kalimantan belum dikatakan pelaksanaannya selaras dengan prosedur yang ditetapkan.

\section{Saran}

a. Harus lebih meningkatkan komitmen pegawai agar pegawai tersebut mampu bekerja secara maksimal sehingga pegawai dapat memposisikan dirinya dalam suatu instansi serta turut serta dalam mewujudkan tujuan yang ingin dicapai.

b. Pegawai harus lebih memahami dengan tugas pokok dan fungsinya sehingga pegawai dapat cepat dan tanggap apabila diperintahkan untuk menyelesaikan suatu pekerjaan agar tidak terjadi penumpukan pekerjaan.

c. Kedisiplinan pegawai harus lebih ditingkatkan agar pegawai dapat menyelesaikan pekerjaannya tepat waktu sesuai dengan yang diperintahkan oleh pimpinan dan juga kedisiplinan dalam hal absensi agar pegawai tidak seenaknya meninggalkan kantor dan pekerjaan di jam-jam kerja.

d. Tanggungjawab pegawai harus lebih ditingkatkan yaitu dalam hal pekerjaan agar pegawai dapat menyelesaikan pekerjaan sesuai dengan waktu yang telah ditentukan dan juga untuk kehadiran pegawai harus lebih ditingkatkan sehingga apabila ada pegawai yang tidak masuk kerja tanpa ada surat keterangan agar ditindak tegas oleh pimpinan sehingga pegawai tersebut memiliki efek jera dan tidak akan mengulanginya lagi.

e. Kemandirian pegawai juga harus lebih ditingkatkan sehingga pegawai dapat menyelesaikan pekerjaannya sesuai dengan tugas pokok dan fungsinya dan juga dapat menyelesaikan pekerjaannya sesuai dengan kemampuan pegawai tersebut tanpa meminta bantuan dari orang lain.

f. Penyampaian laporan akuntabilitas kinerja instansi pemerintah (LAKIP) setiap tahunnya sudah sesuai dengan format penyusunan dengan mengikuti ketentuan yang ada agar ini dapat lebih ditingkatkan lagi sehingga dapat lebih memperbaiki kinerja pegawai tersebut.

g. Harus ada pembagian tugas yang jelas antara pegawai dan tenaga kontrak sehingga pegawai tersebut tidak seenaknya memerintahkan tenaga kontrak untuk mengerjakan tugas pokok dan fungsi dari pegawai tersebut.

h. Pimpinan harus bertindak tegas apabila ada pegawai yang dengan sengaja mengalihkan pekerjaan dari tugas pokok dan fungsi pegawai tersebut kepada tenaga kontrak agar pegawai tersebut tidak mengulangi perbuatannya itu lagi.

i. Tenaga kontrak hanya membantu pegawai dalam hal pekerjaan bukan untuk mengalihkan tugas pokok dan fungsi dari pegawai tersebut.

\section{Daftar Pustaka}

\section{Buku}

Alwasilah, Chaedar. 2017. Pokoknya Kualitatif Dasar-Dasar Merancang dan Melakukan Penelitian Kualitatif. PT Dunia Pustaka Jaya. Bandung.

Bungin, B. 2005. Metodologi Penelitian Kualitatif. Prenada Media Group. Jakarta.

Edison, Emron. Yohny Anwar. Imas Komariyah. 2017. Manajemen Sumber Daya Manusia 
Strategi dan Perubahan Dalam Rangka Meningkatkan Kinerja Pegawai dan Organisasi. CV Alfabeta. Bandung

Edwards III, George C. 1980. Implementing Public Policy. Washington: Congressional Quarterly Inc.

Faisal, Sanapiah. 2001. Format-Format Penelitian Sosial. PT Raja Grafindo Persada. Jakarta.

Hasibuan, Malayu. 2005. Organisasi dan Motivasi. PT Bumi Aksara. Jakarta.

Hasibuan, Malayu. 2006. Manajemen Sumber Daya Manusia. Edisi Revisi. PT Bumi Aksara. Jakarta.

Mahmudi. 2015. Manajemen Kinerja Sektor Publik. Edisi Ketiga. UPP STIM YKPN. Yogyakarta.

Moleong, L. J. 1989. Metodologi Penelitian Kualitatif. Remaja Karya. Bandung.

Pasolong, Harbani. 2007. Teori Administrasi Publik. Alfabeta. Bandung.

Priansa, Donni Juni. 2018. Manajemen Kinerja Kepegawaian dalam Pengelolaan SDM Perusahaan. CV Pustaka Setia. Bandung.

Robbins, Stephen P. 2006. Perilaku Organisasi. PT Indeks Kelompok Gramedia. Jakarta.

Simamora, Henry. 2006. Manajemen Sumber Daya Manusia. Edisi III. Bagian Penerbitan Sekolah Tinggi Ilmu Ekonomi YKPN. Yogyakarta.

Sinambela, Lijan Poltak. 2018. Manajemen Sumber Daya Manusia Membangun Tim Kerja yang Solid untuk Meningkatkan Kinerja. PT Bumi Aksara. Jakarta.

Suparyadi. 2015. Manajemen Sumber Daya Manusia Menciptakan Keunggulan Bersaing Berbasis Kompetensi SDM. CV Andi Offset. Yogyakarta.

Wibowo. 2017. Manajemen Kinerja. Edisi Kelima. Rajawali Pers. Depok.

Wirawan. 2009. Evaluasi Kinerja Sumber Daya Manusia Teori, Aplikasi dan Penelitian. Salemba Empat. Jakarta.

\section{Peraturan:}

TAP MPR Nomor XI/MPR/1998 Tentang Pemyelenggaraan Negara yang Bersih dan Bebas Korupsi, Kolusi dan Nepotisme.

Undang-Undang Nomor 28 Tahun 1999 Tentang Penyelenggaraan Negara yang Bersih dan Bebas Korupsi, Kolusi dan Nepotisme.

Undang-Undang Republik Indonesia Nomor 43 Tahun 1999 Tentang Pokok-Pokok Kepegawaian.

Undang-Undang Republik Indonesia Nomor 5 Tahun 2014 Tentang Aparatur Sipil Negara.

Instruksi Presiden Nomor 7 Tahun 1999 Tentang Akuntabilitas Kinerja Instansi Pemerintah (AKIP).

Peraturan Presiden Nomor 29 Tahun 2014 Tentang Sistem Akuntabilitas Kinerja Instansi Pemerintah.

Peraturan Pemerintah Nomor 8 Tahun 2006 Tentang Pelaporan Keuangan dan Kinerja Instansi Pemerintah.

Peraturan Pemerintah Nomor 53 Tahun 2010 Tentang Disiplin Pegawai Negeri Sipil. 